\begin{tabular}{|l|l|l||}
\hline \multicolumn{2}{|c|}{ PublisherInfo } \\
\hline \hline PublisherName & $:$ & BioMed Central \\
\hline \hline PublisherLocation & $:$ & London \\
\hline \hline PublisherImprintName & $:$ & BioMed Central \\
\hline \hline
\end{tabular}

\title{
Pathogenic role of anti-myeloperoxidase ANCA
}

\begin{tabular}{|l|l|l||}
\hline \multicolumn{2}{|c|}{ ArticleInfo } \\
\hline \hline ArticleID & $:$ & 248 \\
\hline \hline ArticleDOI & $:$ & $10.1186 /$ ar-2002-78552 \\
\hline \hline ArticleCitationID & $:$ & 78552 \\
\hline \hline ArticleSequenceNumber & $:$ & 1 \\
\hline \hline ArticleCategory & $:$ & Paper Report \\
\hline \hline ArticleFirstPage & $:$ & 1 \\
\hline \hline ArticleLastPage & $:$ & 3 \\
\hline \hline & & RegistrationDate $: 2002-11-15$ \\
ArticleHistory & $:$ & Received $\quad: 2002-11-15$ \\
& Accepted $\quad: 2002-11-27$ \\
\hline ArticleCopyright & $:$ & Biomed Central Ltd2002 \\
\hline \hline ArticleGrants & $:$ & \\
\hline \hline
\end{tabular}




\begin{tabular}{|l|l|l|}
\hline ArticleContext & $:$ & 130754411 \\
\hline
\end{tabular}

Martin Aringer, ${ }^{\text {Aff1 }}$

Aff1 University of Vienna, Austria

\section{Keywords}

microscopic panarteritis, myeloperoxidase, pauci-immune glomerulonephritis, perinuclear ANCA

\section{Context}

Antineutrophil cytoplasmatic antibodies (ANCA) are present in many patients with systemic vasculitides, with myeloperoxidase (MPO) and proteinase-3 (PR-3) being the main autoantigens in (microscopic) panarteritis nodosa (PAN) and Wegener's granulomatosis (WG), respectively. ANCA are associated with disease activity, but their role in disease pathogenesis has remained obscure.

\section{Significant findings}

Rag2-/- mice lack functional B and T cells. Splenocytes of MPO-/- mice immunized with purified MPO were transferred to Rag2-/- recipients and developed MPO-ANCA. 80\% of Rag2-/- mice receiving $1 \times 108$ or $5 \times 107$ splenocytes from MPO-immunized mice developed a pauci-immune glomerulonephritis with increased serum creatinine and blood urea nitrogen (BUN), proteinuria, an active urinary sediment, and fibrinoid necrosis and crescents in their glomeruli. One third of the animals developed hemorrhagic pulmonary capillaritis, 2/16 developed necrotizing arteritis, and in one animal necrotizing granulomatous inflammation was found in the spleen. Mice receiving 1x108 splenocytes from BSAimmunized or non-immunized animals developed mild glomerular lesions with moderate glomerular hypercellularity. Purified IgG derived from mice immunized with MPO, but not from control animals immunized with BSA, induced pauci-immune crescentic glomerulonephritis both in Rag2-/- and in wildtype B6 mice. 2/6 wildtype B6 mice developed capillaritis; 3/6 had skin ulceration with necrotizing arteritis proven in one case.

\section{Comments}


This article provides definitive evidence that ANCA specific for MPO play an important pathogenic role, even in the absence of $\mathrm{T}$ lymphocytes. The rate of pauci-immune glomerulonephritis is impressive. The results establish this as a useful animal model for WG, and further suggest an important role for cells other than lymphocytes in this autoantibody-mediated disease. While the same concept may well hold true for anti-PR-3 ANCA, inferences made from this study are still speculative. Unfortunately, because most autoantigens (e.g., histones, Smith proteins, pyruvate dehydrogenase complex) cannot be genetically deleted, a similar model cannot be used for most other autoimmune diseases.

\section{Methods}

Rag2-/- mice, B6 mice, immunization of MPO-/- mice with MPO or BSA, splenocytes transfer, IgG transfer, ELISA, histology, immunofluorescence, electron microscopy

\section{Additional information}

The article is accompanied by a commentary (D'Agati V: Antineutrophil cytoplasmic antibody and vasculitis: much more than a disease marker. J Clin Invest 2002, 110: 919-921).

\section{References}

1. Xiao H, Heeringa P, Hu P, Liu Z, Zhao M, Aratani Y, Maeda N, Falk RJ, Jennette JC: Antineutrophil cytoplasmatic autoantibodies specific for myeloperoxidase cause glomerulonephritis and vasculitis in mice. J Clin Invest . 2002, 110: 955-963.

This PDF file was created after publication. 